\title{
BASIC STUDIES ON THE MONGOLIAN GERBIL AS A SUSCEPTIBLE HOST TO FILARIAL INFECTION: COMPARATIVE STUDIES ON SERUM BIOCHEMICAL VALUES BETWEEN THE WILD-COLORED GERBIL AND THE COAT COLOR MUTANTS
}

\author{
Kazuhiro Shichinohe ${ }^{1,2}$, Masumi Shimizu ${ }^{1,2}$, Katsuya HaGa ${ }^{2}$, \\ TETSUO IEDOKORO ${ }^{2}$ AND KOICHIRO FujITA ${ }^{2}$ \\ Received August 30 1993/Accepted October 71993
}

\begin{abstract}
We made a comparative study on serum biochemical values of mature Mongolian gerbils between the wild-colored (agouti) and the coat color mutants of both sexes by autoanalyzers. The coat colors of the mutants were white spotted-agouti, albino, black and white spotted-black. All of serum biochemical values we measured of different coat color gerbils were not significantly different each other. We did not find any lipemic sera and any hyperglycemia in all coat color gerbils. Compare to the other common laboratory rodents, patterns and values of serum protein fractions of the gerbils were different. Namely, A/G ratios and rates of $\gamma$-globulin fraction of gerbils were much higher than those of mice and rats and were the same as those of human beings.
\end{abstract}

\section{INTRODUCTION}

We made a comparative study on serum biochemical values of Mongolian gerbils between the wild-colored (called agouti) gerbils and the coat color mutants of both sexes in this report.

The Mongolian gerbil (Meriones unguiculatus) can be kept and handled so easily in laboratories and is so readily infected with some filarias (Ash and Riley, 1970a,b; Dalesandro and Klei, 1976; Matsuda et al., 1976) that it has been used as an experimental host of filariasis. Biological characteristics of this animal were studied in 1960s when it was started to be used as a laboratory animal (Schwentker, 1963; Ruhren, 1965; Mays, 1969). However after that, it has been raised just only as a material, that means as a host only for providing parasites used for research, and it's own characteristics have not been studied systematically.

Genetic influences on host reactions against filarial infections could not be studied because those gerbils commonly used were only agouti type which was not controlled genetically at all. But we have raised and kept the closed colonies of the coat color mutants of Mongolian gerbils which have white-spotted agouti, albino, black or white-spotted black coat color and those coat color mutants are expected as a model to study influences of genetic background on response against filarial infections. We have studied to characterize the coat color mutants of Mongolian gerbils biologically and hematologically (Shimizu et al., 1990, 1991) and we also need data on serum biochemical values.

\section{MATERIALS AND METHODS}

Mongolian gerbils were fed a commercial pellet for small rodents (MF; Oriental Yeast Inc., Tokyo, Japan) and water ad libitum under a conventional condition and housed 5 animals of the same sex in one cage. The room temperature and the humidity were maintained at $24 \pm$ $2^{\circ} \mathrm{C}$ and $60 \pm 5 \%$, respectively. The coat color mutants of the gerbils maintained in our laboratory were agouti, white-spotted agouti, albino, black and white spotted -black and origins of these gerbils were described in our

1 Department of Laboratory Animal Science, Nippon Medical School, 1-1-5 Sendagi, Bunkyo-ku, Tokyo 113, Japan

2 Department of Medical Zoology, Faculty of Medicine, Tokyo Medical and Dental University, 1-5-45 Yushina, Bunkyo-ku, Tokyo 113, Japan 
Table 1 Serum biochemical values of the agouti type and the coat color mutants of Mongolian gerbils (1)

\begin{tabular}{ccccc}
\hline Coat color & Sex & $\begin{array}{c}\text { Glucose } \\
(\mathrm{mg} / \mathrm{dl})\end{array}$ & $\begin{array}{c}\text { Cholesterol } \\
(\mathrm{mg} / \mathrm{dl})\end{array}$ & $\begin{array}{c}\text { Triglyceride } \\
(\mathrm{mg} / \mathrm{dl})\end{array}$ \\
\hline \multirow{2}{*}{ Agouti } & Male & $89 \pm 10$ & $66 \pm 10$ & $55 \pm 3 *$ \\
& Female & $89 \pm 18$ & $76 \pm 9$ & $37 \pm 10$ \\
\hline \multirow{2}{*}{ White spoted-agouti } & Male & $77 \pm 14$ & $77 \pm 7$ & $81 \pm 17 * *$ \\
& Female & $90 \pm 18$ & $91 \pm 12$ & $45 \pm 2$ \\
\hline \multirow{2}{*}{ Albino } & Male & $91 \pm 18$ & $74 \pm 15$ & $39 \pm 10$ \\
\hline \multirow{2}{*}{ Black } & Female & $102 \pm 19$ & $81 \pm 16$ & $57 \pm 18$ \\
& Male & $88 \pm 14$ & $65 \pm 8$ & $44 \pm 8$ \\
\hline \multirow{2}{*}{ White spotted-black } & Female & $87 \pm 16$ & $62 \pm 18$ & $77 \pm 26$ \\
& Male & $87 \pm 14$ & $63 \pm 9$ & $70 \pm 18$ \\
\hline
\end{tabular}

The values are derived from 14 to 15 -week-old gerbils and represent means \pm standard deviations for 10 gerbils of each group. $*, * *$ The difference between sexes is significant by Student's t-test $(* \mathrm{p}<0.05, * * \mathrm{p}<0.01)$. There are no significant coat color differences in those values.

Table 2 Serum biochemical values of the agouti type and the coat color mutants of Mongolian gerbils (2)

\begin{tabular}{cccccc}
\hline Coat color & Sex & $\begin{array}{c}\text { GOT } \\
(\mathrm{IU} / \mathrm{l})\end{array}$ & $\begin{array}{c}\text { GPT } \\
(\mathrm{IU} / \mathrm{l})\end{array}$ & $\begin{array}{c}\text { LDH } \\
(\mathrm{IU} / \mathrm{l})\end{array}$ & $\begin{array}{c}\text { ALP } \\
(\mathrm{IU} / \mathrm{l})\end{array}$ \\
\hline \multirow{2}{*}{ Agouti } & Male & $388 \pm 152$ & $50 \pm 16$ & $950 \pm 452$ & $164 \pm 47$ \\
& Female & $363 \pm 188$ & $61 \pm 23$ & $728 \pm 476$ & $172 \pm 79$ \\
\hline \multirow{2}{*}{ White spotted-agouti } & Male & $355 \pm 152$ & $41 \pm 22$ & $910 \pm 393$ & $99 \pm 21$ \\
& Female & $408 \pm 120$ & $29 \pm 16$ & $887 \pm 433$ & $88 \pm 22$ \\
\hline \multirow{2}{*}{ Albino } & Male & $436 \pm 97$ & $43 \pm 22$ & $1131 \pm 547$ & $145 \pm 53$ \\
& Female & $276 \pm 103$ & $43 \pm 26$ & $711 \pm 459$ & $151 \pm 25$ \\
\hline \multirow{2}{*}{ Black } & Male & $422 \pm 55$ & $54 \pm 30$ & $1128 \pm 197$ & $121 \pm 43$ \\
& Female & $403 \pm 139$ & $42 \pm 23$ & $1012 \pm 559$ & $129 \pm 29$ \\
\hline \multirow{2}{*}{ White spotted-agouti } & Male & $342 \pm 143$ & $37 \pm 14$ & $900 \pm 205$ & $82 \pm 20$ \\
& Female & $389 \pm 81$ & $34 \pm 11$ & $950 \pm 470$ & $110 \pm 27$ \\
\hline
\end{tabular}

The values are derived from 14 to 15 -week old gerbils and represent means \pm standard deviations for 10 gerbils of each group. Glutamate oxaloacetate transaminase, glutamate pyruvate transaminase, lactate dehydrogenase and alkaline phosphatase are abbreviated to GOT, GPT, LDH and ALP, respectively. There are no sex differences and no coat color differences in those values significantly by Student's t-test.

Table 3 Serum biochemical values of the agouti type and the coat color mutants of Mongolian gerbils (3)

\begin{tabular}{ccccccccc}
\hline Coat color & Sex & $\begin{array}{c}\text { Uric acid } \\
(\mathrm{mg} / \mathrm{dl})\end{array}$ & $\begin{array}{c}\text { Urea } \\
\text { nitrogen } \\
(\mathrm{mg} / \mathrm{dl})\end{array}$ & $\begin{array}{c}\text { Creatinine } \\
(\mathrm{mg} / \mathrm{dl})\end{array}$ & $\begin{array}{c}\text { Sodium } \\
(\mathrm{mEq} / \mathrm{l})\end{array}$ & $\begin{array}{c}\text { Potassium } \\
(\mathrm{mEq} / \mathrm{l})\end{array}$ & $\begin{array}{c}\text { Chloride } \\
(\mathrm{mEq} / \mathrm{l})\end{array}$ & $\begin{array}{c}\text { Calcium } \\
(\mathrm{mg} / \mathrm{dl})\end{array}$ \\
\hline \multirow{2}{*}{ Agouti } & Male & $1.2 \pm 0.9$ & $23 \pm 8$ & $0.4 \pm 0.1$ & $157 \pm 2$ & $7.3 \pm 1.5$ & $121 \pm 3$ & $8.8 \pm 0.3$ \\
& Female & $0.7 \pm 0.2$ & $31 \pm 5$ & $0.5 \pm 0.1$ & $157 \pm 6$ & $7.0 \pm 0.9$ & $123 \pm 6$ & $8.8 \pm 0.7$ \\
\hline $\begin{array}{c}\text { White spotted- } \\
\text { agouti }\end{array}$ & Male & $0.5 \pm 0.3$ & $26 \pm 6$ & $0.5 \pm 0.1$ & $156 \pm 2$ & $6.5 \pm 2.1$ & $122 \pm 2$ & $7.7 \pm 0.8$ \\
\hline \multirow{2}{*}{ Albino } & Female & $0.8 \pm 0.5$ & $25 \pm 2$ & $0.5 \pm 0.1$ & $155 \pm 2$ & $7.8 \pm 1.1$ & $121 \pm 1$ & $8.1 \pm 0.6$ \\
\hline \multirow{2}{*}{ Black } & Male & $0.9 \pm 0.3$ & $31 \pm 2$ & $0.5 \pm 0.1$ & $149 \pm 3$ & $10.7 \pm 1.2$ & $119 \pm 3$ & $9.0 \pm 0.8$ \\
& Female & $1.2 \pm 1.1$ & $21 \pm 13$ & $0.5 \pm 0.1$ & $147 \pm 9$ & $9.4 \pm 2.3$ & $113 \pm 10$ & $9.4 \pm 0.6$ \\
\hline White spotted- & Male & $0.8 \pm 0.2$ & $18 \pm 3$ & $0.3 \pm 0.1$ & $151 \pm 2$ & $9.5 \pm 0.7$ & $118 \pm 1$ & $9.0 \pm 0.7$ \\
black & Male & $0.7 \pm 0.4$ & $18 \pm 3$ & $0.3 \pm 0.1$ & $149 \pm 3$ & $8.7 \pm 0.8$ & $115 \pm 4$ & $9.1 \pm 0.9$ \\
\hline
\end{tabular}

The values are derived from 14 to 15 -week old gerbils and represent means \pm standard deviations for 10 gerbils of each group.

There are no sex differences and no coat color differences in those values significantly by Student's t-test. 
Table 4 Serum biochemical values of the agouti type and the coat color mutants of Mongolian gerbils (4)

\begin{tabular}{ccccc}
\hline Coat color & Sex & Total protein $(\mathrm{g} / \mathrm{dl})$ & Albumin $(\mathrm{g} / \mathrm{dl})$ & A/G ratio \\
\hline \multirow{2}{*}{ Agouti } & Male & $5.98 \pm 0.30$ & $3.61 \pm 0.16$ & $1.56 \pm 0.29$ \\
& Female & $6.24 \pm 0.34$ & $3.68 \pm 0.22$ & $1.44 \pm 0.09$ \\
\hline \multirow{2}{*}{ White spotted-agouti } & Male & $5.92 \pm 0.15$ & $3.61 \pm 0.13$ & $1.57 \pm 0.18$ \\
& Female & $6.32 \pm 0.25$ & $3.65 \pm 0.18$ & $1.39 \pm 0.25$ \\
\hline \multirow{2}{*}{ Albino } & Male & $5.86 \pm 0.21$ & $3.49 \pm 0.08$ & $1.47 \pm 0.11$ \\
& Female & $5.80 \pm 0.32$ & $3.60 \pm 0.13$ & $1.68 \pm 0.37$ \\
\hline \multirow{2}{*}{ Black } & Male & $5.62 \pm 0.15$ & $3.39 \pm 0.10$ & $1.53 \pm 0.20$ \\
& Female & $5.94 \pm 0.21$ & $3.56 \pm 0.14$ & $1.52 \pm 0.27$ \\
\hline \multirow{2}{*}{ White spotted-black } & Male & $5.84 \pm 0.39$ & $3.50 \pm 0.13$ & $1.51 \pm 0.20$ \\
& Female & $5.76 \pm 0.27$ & $3.45 \pm 0.08$ & $1.51 \pm 0.23$ \\
\hline
\end{tabular}

The values are derived from 14 to 15-week-old gerbils and represent means \pm standard deviations for 10 gerbils of each group. There are no sex differences and no coat color differences in those values significantly by Student's t-test.

previous report (Shimizu et al., 1990). Ten animals of each coat color of both sexes aged 14 to 15 weeks old were used in the experiment.

Samples of blood were collected from the hearts of animals anesthetized with ether in the morning after overnight fasting. They were centrifugalized and the sera were stored at $-80^{\circ} \mathrm{C}$ until assays.

The autoanalyzer, Hitachi 736 (Hitachi co. Ltd. Japan) or Spotchem (Kyoto Daiichi Kagaku co. Ltd. Japan) was used to measure the followings: glucose (GOD-POD), glutamate oxaloacetate transaminase (GOT) (OAC-POP-POD), glutamate pyruvate transaminase (GPT) (POP-POD), lactate dehydrogenase (LDH) (lactate pyruvate method), alkaline phosphatase (ALP) (p-nitrophenylphosphate), cholesterol (CE-COD-POD), triglyceride (LPL-GYOD-POD), uric acid (uricase-POD), urea nitrogen (urease method), creatine (Jaffe reaction), sodium, potassium and chloride (electrode), calcium (OCPC), total protein (BCG) . Protein fractions were measured by using electrophoresis. Those values were evaluated statistically by Student's t-test.

\section{RESULTS}

Table 1 to 4 show serum biochemical values of Mongolian gerbils including the coat color mutants after overnight fasting. Means of some biochemical values were as follows: glucose $77-102 \mathrm{mg} / \mathrm{dl}$, cholesterol $62-81$ $\mathrm{mg} / \mathrm{dl}$, triglyceride $37-81 \mathrm{mg} / \mathrm{dl}$ (Table 1), GOT 276-436 IU/1, LDH 712-1131 IU/1 (Table 2), uric acid 0.5-1.4 $\mathrm{mg} / \mathrm{dl}$ in males and $0.7-1.4 \mathrm{mg} / \mathrm{dl}$ in females (no sex difference) (Table 3), total protein $5.62-6.32 \mathrm{~g} / \mathrm{dl}, \mathrm{A} / \mathrm{G}$ ratio 1.39-1.68 (Table 4).

Figure 1 shows patterns of serum protein fractions of
Mongolian gerbils. Mean values of all coat color gerbils of each fraction were as follows: Albumin 57.8-62.3\%, $\alpha_{1}$-globulin $1.9-2.5 \%, \alpha_{2}$-globulin 8.8-11.1\%, $\beta$-globulin $4.4-9.2 \%, \gamma$-globulin $18.1-23.6 \%$.

All the values we measured were not significantly different between the agouti gerbil and the coat color mutants.

\section{DISCUSSION}

The present paper is the first report of a comparative study on serum biochemical values between the agouti type and the coat color mutants of Mongolian gerbils. In this experiment, significant differences between the agouti gerbil and the coat color mutants were not detected in serum biochemical values. But some values of the agouti gerbils were different from those reported by earlier workers.

Mays (1969) reported that uric acid value had male dominance in Mongolian gerbils, but we could not find such sex difference in that of each coat color gerbil (Table 3). Activity of $\boldsymbol{\gamma}$-glutamyltranspeptidase of gerbils (data not shown) was under measurable level similar to that of the other small rodents (Tanimoto, 1988). GOT and LDH of gerbils were extremely higher than those of rats and mice (Table 2). As those samples were not hemolysis and those data were re-confirmed, we thought that is one of particular characteristics of gerbils. The more precise experiments in future are needed to determine it. All the sera from total 100 gerbils we tested were not lipemic at all, although earlier workers pointed out that $30 \%$ of the sera were lipemic (Ruhren, 1965; Rich; 1968; Mays, 1969). This difference might be caused by that earlier workers did not establish the suitable way of feeding for gerbils 

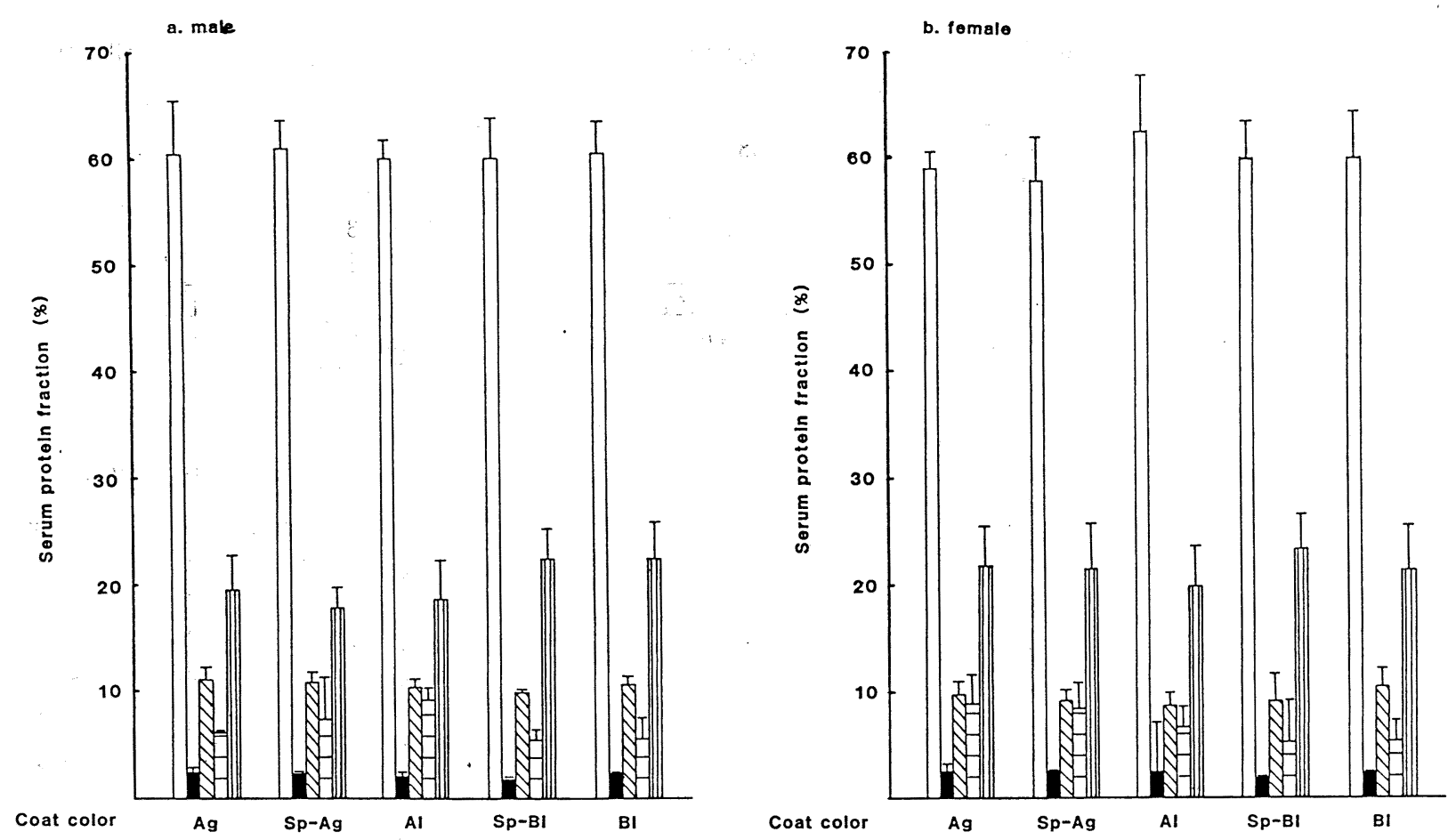

Figure 1 Serum protein fractions of the agouti type and the coat color mutants of male (a) and female (b) Mongolian gerbils. The values are derived from 14 to 15 -week-old gerbils and represent means \pm standard deviations for 10 gerbils of each group. The coat colors of agouti, white spotted-agouti, albino, black and white spotted-black are abbreviated to $\mathrm{Ag}, \mathrm{Sp}-\mathrm{Ag}, \mathrm{Al}, \mathrm{Bl}$ and $\mathrm{Sp}-\mathrm{Bl}$, respectively. Each bar represents one of protein fractions as follows; $\square$ albumin, $\square \alpha_{1}$-globulin, $M \alpha_{2}$-globulin, $\square \square \beta$ -globulin and $\rightleftharpoons \gamma$-globulin. There are no sex differences and no coat color differences in those values significantly by Student's t-test.

which were newly used as a laboratory animal in those days. Now they are raised in certain condition with nutritionally well-balanced commercial pellets. In fact, values of total cholesterol and triglyceride of gerbils were not so high and similar to those of the other common laboratory rodents (Wolford et al., 1986). Nakama (1977) reported that the Mongolian gerbil was hereditary spontaneously diabetic animal. Bonquist (1972) said that there were a few animals which showed diabetes-like symptoms in a stock of old obese gerbils. But glucose values we tested were within a normal range like mice, rats (Wolford et al., 1986) and humans (Ishii et al., 1981) and glucosuria has not been observed at all either (data not shown). Moreover, food and water intake of gerbils has been stable (Shimizu et al., 1990). These facts reveal that the Mongolian gerbil is not a hereditary spontaneously diabetic animal in general.

The patterns of serum protein fractions of gerbils were very different from those of rats and mice. Namely, A/G ratios (Table 4) and rates of $\gamma$-globulin fraction (Figure 1) of the Mongolian gerbils were much higher than those of rats and mice and were the same as those of human beings (Ishii et al., 1981; Tanimoto, 1989). As globulin value changes according to environmental conditions, the breeding conditions of gerbils might bring the same level of globulin as human beings. Namely, gerbils in our laboratory have been kept under bacteriologically unsterilized condition called conventional condition and that condition was bacteriologically the same as where human beings live. We think that is one of advantages of the gerbil as an experimental model of human filariasis as well as their peculiar sensitivity because the breeding condition of animals would effect on sensitivity to parasites (Shichinohe et al., 1990). The Mongolian gerbil has been known to be the most successful host for experimental filariasis such as Brugia spp. (Ash and Riley, 1970a,b), Dipetalonema vitae (Dalensandro and Klei, 1976) and Litomosoides carinii (Matsuda et al., 1976). This character of the gerbil is really valuable because it is very expensive and difficult for studies of filariasis to use their own natural hosts in laboratories. For example, natural mammalian hosts of Brugia pahangi are monkeys, cats and dogs (Edeson, 1959; Edeson and Wilson, 1964) and numerous attempts to introduce this worm into commonly avail- 
able laboratory rodents such as rats and mice have been failed (Laing et al., 1961; Ahmed, 1967; Ash and Riley, 1970b; Sucharit and MacDonald, 1973). However, the reason why gerbils are readily infected with them has not been fully understood. The earlier studies on experimental filarial infections in Mongolian gerbils suggested that the sensitivity of gerbils to filarial worms were brought by less responsivility of cellular immunity against parasites (Lammie and Katz, 1983; Klei et al., 1990). On humoral immunity of gerbils, they had IgG antibody (Tomisato et al., 1983; Farrar et al., 1991), IgE -like antibody in their intact sera, produced it against worm antigen derived from Dirofilaria immitis (Shichinohe et al., 1992) and much higher $\gamma$-globulin level than mice and rats in the present experiment. These facts that gerbils had enough components of humoral immunity were thought to be interesting in contrast with their peculiar sensitivity to parasites. They might indirectly support the statement of earlier workers that their sensitivity was caused by less cellular immunoreactivity.

Mongolian gerbils commonly used were only agouti type and their genetic background have not been controlled at all in contrast with rats and mice which have been controlled genetically to establish many inbred strains. We have studied characteristics of the coat color mutants of gerbils as compared with the agouti gerbil and until now, we have not found any significant differences between the agouti gerbil and the coat color mutants in the serum biochemical values as well as in biological and hematological values (Shimizu et al., 1990, 1991). Then, if the different coat color gerbils will respond differently each other against filarial infection, it is thought that genetic background of gerbils effects on response against filarial infection. Consequently, present study on serum biochemical values of the Mongolian gerbil would be useful as a basic data to analyze mechanisms of host-parasite relationship using gerbils and the coat color mutants of Mongolian gerbils would be expected an useful model to study an influence of genetic background on reactions against filarial infection.

\section{REFERENCES}

1) Ahmed, S.S. (1967): Studies on the laboratory transmission of sub-periodic Brugia malayi and B. pahangi. I. The resistance of guinea-pigs, rabbits and white mice to infection, Ann. Trop. Med. Parasit., 61, 93-100

2 ) Ash, L.R. and Riley, J.M. (1970a): Development of Brugia pahangi in the jird, Meriones unguiculatus, with notes on infections in other rodents, J. Parasitol., 56, 962 $-968$

3 ) Ash, L.R. and Riley, J.M. (1970b): Development of subperiodic Brugia malayi in the jird, Meriones unguiculatus, with notes on infections in other rodents, J. Parasitol., 56, 969-973

4 ) Bonquist, L. (1972): Obesity and pancreatic islet hyperplasia in the Mongolian gerbil, Diabetologia, 8, 274-282

5 ) Dalesandro, D.A. and Klei, T.R. (1976): Evidence for immunodepression of syrian hamster and Mongolian jirds by Dipetalonema vitae infections, Trans. R. Soc. Trop. Med. Hyg., 70, 534-535

6 ) Edeson, J.F.B. (1959): Studies on filariasis in Malaya: the periodicity of the microfilariae of Brugia malayi and B. pahangi in animals, Ann. Trop. Med. Parasit., 53, 381 $-387$

7 ) Edeson, J.F.B. and Wilson, T. (1964): The epidemiology of filariasis due to Wuchereria bancrofti and Brugia malayi, A. Rev. Ent., 9, 245-268

8 ) Farrar, R.G., Klei, T.R., McVay, C.S. and Coleman, S.U. (1991): Quantitative characterization of antibody responses to single and multiple Brugia pahangi infection in jirds, J. Parasitol., 77, 718-726

9 ) Ishii, A., Toyama, T. and Sakaguchi, T. (Traslated) (1981): Clinical biochemical and hematological reference values in normal experimental animals and normal humans, Mitruka, B.M. and Rawnsley, H.M. 2nd ed., 345pp., Seishi shoin Ltd., Tokyo

10) Klei, T.R., McVay, C.S., Dennis, V.A., Coleman, S.U., Enright, F.M. and Cassey, H.W. (1990): Brugia pahangi; Effects of duration of infection and parasite burden on lymphatic lesion severity, granulomatous hypersensitivity and immune responses in jirds (Meriones unguiculatus), Expl. Parasitol., 71, 393-405

11) Laing, A.B.G., Edeson, J.F.B. and Wharton, R.H. (1961): Studies on filariasis in Malaya: further experiments on the transmission of Brugia malayi and Wuchereria bancrofti, Ann. Trop. Med. Parasit., 55, 86-92

12) Lammie, P.J. and Katz, S. (1983): Immunoregulation in experimental filariasis II; Responses to parasite and non -parasite antigen in jirds with Brugia pahangi, J. Immun., 130, 1386-1389

13) Matsuda, H., Takaoka, M. and Tanaka, H. (1976): Effect of diethylcarbamazine on microfilaria of Litomosoides carinii in jird, Meriones unguiculatus, Jpn. J. Parasitol., 25, 94-98

14) Mays, A. Jr. (1969): Beseline hematological and biochemical parameters of the Mongolian gerbil (Meriones unguiculatus), Lab. Anim. Care, 19, 838-842

15) Nakama, K. (1977): Studies on diabetic syndrome and influences of long-term tolbutamide administration in Mongolian gerbils (Meriones unguiculatus), Endocrinol. Japon., 24, 421-433

16) Rich, S.T. (1968): The Mongolian gerbil (Meriones unguiculatus) in research, Lab. Anim. Care, 18, 235-243

17) Ruhren, R. (1965): Normal values for hemoglobin concentration and cellular elements in the blood of Mon- 
golian gerbils, Lab. Anim. Care, 15, 313-320

18) Schwentker, V. (1963): The gerbil; A new laboratory animal, Illinois Vet., 6, 5-9

19) Shichinohe, K., Shimizu, M., Asakawa, M. and Ishizaki, M. (1990): Effect of rearing conditions on Encephalomyocarditis (EMC) virus-induced diabetes in mice, Exp. Anim., 39, 377-381

20) Shichinohe, K., Shimizu, M., Kato, K., Tamura, N., Tsukidate, S. and Fjita, K. (1992): Basic studies on the Mongolian gerbil as a susceptible host to filarial infection; IgE-like antibody formation against Dirofilaria immitis adult worm antigen, Jpn. J. Trop. Med. Hyg., 20, 271-281

21) Shimizu, M., Shichinohe, K., Tsukidate, S. and Fujita, K. (1990): Basic studies on the Mongolian gerbil as a susceptible host to filarial infection; Comparative studies on growth and reproduction among coat color mutants and genetic analysis of coat colors, Japan J. Trop. Med. Hyg., 18, 301-310

22) Shimizu, M., Shichinohe, K., Tsukidate, S. and Fujita, K. (1991): Basic studies on the Mongolian gerbil as a susceptible host to filarial infection; Comparative studies on hematological features between the wild -colored gerbil and the coat color mutants, Jpn. J. Trop. Med. Hyg., 19, 331-338

23) Sucharit, S. and MacDonald, W.W. (1973): Brugia pahangi in small laboratory animals: attempts to increase susceptibility of white rats to Brugia pahangi by host selections, S.E. Asian. J. Trop. Med. Publ. Hlth., 4, 71-77

24) Tanimoto, Y. (1988): Biochemistry of blood and urine in experimental animals, Laboratory Animal Series, 5, 189pp., Soft Science Inc., Tokyo

25) Tanimoto, Y. (Ed.) (1989): Serum biochemical finding, Tajima, Y. (Supervised), Biological reference data book on experimental animals, 151-201, Soft Science Inc., Tokyo

26) Tomisato, M., Nakajima, Y., Nariuchi, H. and Nogami, S. (1983): Detection of IgG antibodies in Mongolian jirds infected with Brugia pahangi by enzyme-linked immunosorbent assay, Jap. J. Parasit., 32, 43-54

27) Wolford, S.T., Schroer, R.A., Gohs, F.X., Gallo, P.P., Brodeck, M., Falk, H.B. and Ruhren, R. (1986): Reference range data base for serum chemistry and hematology values in laboratory animals, J. Toxicol. Environm. Health, 18, 161-188 